Philippine Political Science Journal 29 (52) 2008

\title{
Looking into the Future of Moro Self-Determination in the Philippines
}

\section{Rizal G. Buendia*}

\begin{abstract}
This paper examines the concept, theory, and practice of the right to self-determination as applied in some countries. The secessionist movement in the Philippines led by the Moro Islamic Liberation Front (MILF) has focused and relied on the international community to support its struggle for a Bangsa Moro (Moro Nation) right to self-determination. However, the reality in the world state system is the protection of the state's territorial integrity rather than its impairment. The paper argues that the internationally-recognized right to self-determination is a shaky promise of independence to nations and peoples who seek independence from the state. Unless the state addresses the fundamental grievances of Muslims in the Philippines in appropriate, relevant, and timely policies that substantially and tangibly work toward greater democracy, deeper participation, and better governance, secessionism as a political alternative cannot be completely disregarded as a final option.
\end{abstract}

Key Words: self-determination, Moro, Philippines, MILF, peace, Mindanao.

\section{Introduction}

The search for substantial political autonomy among Muslims in the Philippines continues. The failure of the state to ensure meaningful autonomy through the formal structures of regional government, the Autonomous Region in Muslim Mindanao (ARMM) created in 1990, has left the Moro Islamic Liberation Front (MILF) the option of achieving self-governance using the guarantees of international laws on the right of peoples and nations to self-determination.

* The author acknowledges the useful comments of two anonymous reviewers but assumes full responsibility for the final manuscript. 
This paper examines the prospect of self-determination as an alternative route towards Bangsamoro's political independence from the Philippine state. It analyzes relevant provisions of international laws and covenants as well as practices of the international system in operationalizing the concept of the right to self-determination (RSD).

The paper argues that while international laws and covenants flaunt the right of peoples and nations to self-determination, the international state system ensures that the state's territorial integrity is upheld and respected. This makes the right to self-determination an arduous path to people who cherish to live separately from the state.

\section{The Moro self-determination in brief historical perspective}

The quest of the Muslims of Mindanao to create their own sovereign state is hinged on the people's continued definition and re-definition of their national identity. Called Moro' by the Spaniards, the notion of Muslim nationhood crystallized when the Philippines was still a colony of the United States (US) of America. Beginning in early 1920s, Muslim leaders of Sulu and Mindanao began a peaceful movement that asserted their right to establish their own nation-state and form a government of their choice. Leaders petitioned and offered the following alternatives for the US Congress to consider: One, that Mindanao, Sulu and Palawan become part of the Federal Government of the United States; two, be declared as a separate sovereign state from the would-be Republic of the Philippines; and three, be made an unorganized territory of the US. The last option rests on the hope that Muslims would gain their independence in the event that the US finally relinquishes its power over colonies and other non-governing territories in the future (see Gowing 1979; Tan 1993; Lingga 2002 for detailed account). Notably, being part of the Philippine state was not in any way considered.

The denial of their petition as well as the rejection of the Bacon Bill of 1926 in the US Congress which proposed that Mindanao and Sulu become one of the states of the US on the one hand, and inevitability of Philippine independence after an American sponsored 10-year transition 
period under a Commonwealth Republic on the other hand, led Muslim leaders to reconfigure their identity in line with the impending Philippine nation-state. Muslim leaders declared themselves as "Filipinos" and considered Moro-pejoratively associated with piracy, savagery, slavery, treachery, amok (juramentado), and other negative connotations-as a name that is unacceptable.

Even so, the last-ditch effort of Muslims to live separately from Christian Filipinos was made in 1935 (the year when the Commonwealth Republic was inaugurated) when Lanao leaders appealed to the US government and the American people to exclude Mindanao and Sulu in the proposed independence to the Filipinos. The same proposal was trashed.

The difficult, often bloody process of integrating Muslims into the Philippine body politic and centralized power of the state took over 30 years from the time the Commonwealth Republic was established, interrupted only during the Second World War. Muslim traditional and modern political elite who took part in the process of strengthening the Filipino-ness into the consciousness of Muslim masses did not only fail but generated a counter-consciousness that challenge the self-ascribed identity promoted by the Muslim elite.

The emergence of new intellectuals and counter-elite among the Muslims and the political events that transpired in the late 1960s until early 1970s triggered the re-invention of Muslim identity. The massacre of about 28 Muslim military trainees (called "Jabidah commandos") in Corregidor Island in March 1968 rekindled the quest of Muslims for independence after almost 50 years when it was first clamored in the 1920 s.

Although traditional Muslim politicians formed their own organization that appears to have secessionist intentions, like the Muslim (later renamed Mindanao) Independence Movement (MIM) set up by then Cotabato Province's Governor, Datu Udtog Matalam, ${ }^{2}$ and the Bangsa Moro Liberation Organization (BMLO) founded by then member of the 
House of Representatives (HOR) Raschid Lucman ${ }^{3}$ in 1968 and 1971 respectively, non-traditional politico and intellectual Nur Misuari's Moro National Liberation Front (MNLF) was the only Muslim organization that militarily challenged the state for more than two decades (1971-1996) in its bid to secede 13 out of 25 provinces of Mindanao island from the Republic.

The MNLF's vision of a secessionist war was emphatically secular in orientation rather than Islamic. Its goal is to reclaim the Bangsa Moro (Moro Nation) ${ }^{4}$, the Muslims' homeland that has been "unjustifiably annexed by the Philippine state." Misuari called upon his brethren to renounce their identities as Filipino-Muslims and declare their identity and nationality as Moro, a reincarnation of the pre-colonial identity as the descendants of the "unsubjugated" and "uncolonized" peoples.

The Bangsamoro struggle is an expression of a "reactive nationalism," articulated by the new and non-traditional counter-elite on a reactive basis, and resonates with Muslim society which is undergoing some "crisis of self-confidence." It demonizes the threats of the state as the enemy and mobilizes the masses to take collective action against such threats. It has to appeal to an educated Muslim middle class and is invariably populist, intended to induct the masses into politics.

Nonetheless, the independence movement was never united from the time Misuari called for Moro national unity. The self-determination struggle has been saddled with leadership crisis and power struggles between and among the three major Moro ethnic groups - Tausug, Maguindanaoan, and Maranao. The movement suffered from no less than five major splits and factions (Buendia 2005: 116-118). The issue of Moro unification has been the overriding concern not only by the Moro leaders and masses themselves but also those which support Muslim self-governance and autonomy struggle like the Organization of Islamic Conference $(\mathrm{OIC})^{5}$, the Muslim World League $(\mathrm{MWL})$, and the Muslim World Congress (MWC).

When the MNLF signed the Final Peace Agreement (FPA) with the Government of the Republic of the Philippines (GRP) in 1996, the MNLF-

4 Philippine Political Science Journal 29 (52) 2008 
led secessionist war ended but carried forward by the Moro Islamic Liberation Front (MILF). ${ }^{6}$ The MILF is now the most potent armed organization pursuing the Moro secessionist movement. The government has acknowledged its armed capability to threaten the territorial integrity of the state.

Notwithstanding the ideological differences between the MNLF and MILF — the former as more secular while the latter being more Islamic — they see themselves as "one people." The consciousness of being one people distinct from the neighboring peoples, the Filipinos, Bangsamoro is articulated and self ascribed, bound collectively on the basis of a common ancestry, history, society, institutions, territory, and more importantly, religion.

The late MILF Chairman Salamat Hashim believed that what the GRPMNLF FPA resolved was the government's problem and not the Bangsamoro problem, "the agreement never touched the core of the Bangsamoro problem which is the illegal and immoral usurpation of their (referring to the Moros) ancestral homeland and legitimate rights to freedom and self-determination". ${ }^{7}$

Hashim's successor, Al Haj Murad Ebrahim expressed in his message delivered on the occasion of the fasting month of Ramadhan in November 2003, that "there can be no genuine peace and development unless the right of the Bangsamoro people to self-determination is adequately addressed." 8 In an effort to pursue the "self-determination" agenda in the GRP-MILF peace talks, the MILF pushes the issue of ancestral domain. It hopes that government's recognition of the right of the Bangsamoro over their ancestral domain will eventually result to the acknowledgement of Moros' territory.

\section{What is said and done}

The concept and definition self-determination is broad and encompasses both external and internal dimensions of self-determination. External self-determination usually refers to the right of people to secede 
its conceived territory from an existing state. Internal self-determination concerns the choice of a system of governance and the administration of the functions of governance according to the will of the governed.

In both respects, self-determination is an acknowledged principle of the basic human right of individuals to participate in democratic governance. This includes the individual's right to engage in the political, economic or cultural system of the state. Secondly, it is also a collective right of groups as national, religious, ethnic or linguistic minorities to express, practice, and promote their own culture, life-ways, language, and religion which require protection from the state. Thirdly, it is a guaranteed right of people to their homeland or claimed territory which embodies their identity, culture, and political autonomy. Finally, the right to self-determination, especially the claim to one's territory, has to enjoy the state's consent. While people are entitled to their territory, this does not necessarily extend to a free determination of the international legal status of the territory. The right is bounded by the endorsement or rejection by the state concerned taking into account the physical or geographical and demographical changes that have occurred in the area that people have "historical claim."9

The different meanings of self-determination have varied implications both to the peoples and the state in asserting their legal and inherent right under the doctrine of self-determination. The right of a group with a distinctive politico territorial identity to determine its own destiny is the political translation of aspirations in the demands for self-determination. Judge Hardy Dillard of the International Court of Justice (ICJ), writing in his Individual Opinion in the 1975 Western Sahara Case, says that: "It is for the people to determine the destiny of the territory and not the territory the destiny of the people" (ICJR 1975: 144).

One of the most vital reasons for people in exercising control over a piece of territory is that it reifies power. Tillich points out:

Being means having space or, more exactly, providing space for oneself. This is the reason for the tremendous importance of 
geographical space and the fight for its possession by power groups. The struggle is not simply an attempt to remove another group from a given space. The real purpose is to draw this space into a larger power field, to deprive it of a centre of its own (Williams 1988: 217).

What makes the right to self-determination so difficult to clarify is that its exercise involves a clash of fundamental world order principles. On the one side is the sense that peoples have the right to statehood. Articles 1 (2) and 55 of the United Nations (UN) Charter have embodied the principle of self-determination as one of its guiding philosophies. The Universal Declaration of Human Rights (UDHR) pursued the issue further by stating that self-determination is not simply a principle but a right of everyone to "liberty." The International Covenants on Human Rights-The International Covenant on Economic, Social, and Cultural Rights (ICESCR) and the International Covenant on Civil and Political Rights (ICCPR)—specifically provide in Article 1 of each that:

All peoples have the right of self-determination. By virtue of that right they freely determine their political status and freely pursue their economic, social and cultural development. (UNHR 1978)

On the other side is the principle of upholding the territorial sanctity of existing states.

The adoption of the 1960 Declaration on the Granting of Independence to Colonial Countries and Peoples (DGICCP) in the form of a General Assembly Resolution is instructive. It confirms the right to self-determination in relation to colonialism and denies some forms of the right's wider application. Evidently, it appreciates the inevitable tension between the exercise of the right to self-determination and the parallel set of rights associated with territorial integrity of existing and emerging sovereign states. Thus, it reiterates Article 1 of the ICESCR and ICCPR in its Operative Provision 2 but at the same time qualifies such right in its Provision 6 which reads: 
Any attempt at the partial or total disruption of the national unity and the territorial integrity of a country is incompatible with the purposes and principles of the Charter of the United Nations (UNGA Resolution 1514, December 1960).

Provision 6 of the DGICCP culminated in the adoption of the influential Declaration of Principles Concerning Friendly Relations and Co-operation Among States in 1970 as the UN General Assembly Resolution 2625. The resolution accepted the principle of the right to self-determination that is linked to the notion of "equal rights of peoples" but cautioned that the right shall not be construed as:

... authorizing or encouraging any action which would dismember or impair, totally or in part, the territorial integrity or political unity of sovereign and independent States conducting themselves in compliance with the principle of equal rights and selfdetermination of peoples ... and thus possessed of a government representing the whole people belonging to the territory without distinction as to race, creed or colour. (UNGA Resolution 2625, 24 October 1970)

The assurance of territorial unity is now made contingent on the government being representative of the whole people and institution of fairness which pursues non-discriminatory policies in relation to "race, creed, or color," and full right to self-determination (including secession) pertains only in colonial situations. It is intended and administered in a way that is consistent with the territorial designs and administrative practices imposed by the colonizers rather than the "people determin(ing) the destiny of the(ir) territory" as Dillard assumes.

Dillard's dictum indicates that accidents of geography and of historically established territorial divisions are not limitations to peoples' collective free will and decision to shape their destiny. This presupposes that if the formation of the state is a product of peoples' collective action, then they also have the power and right to undo it. Hence by logical extension, groups and peoples living within an existing state must also 
be able to assert their will by deciding to leave it, carve a new sovereign unit out of an existing one, or re-claim a state which had existed before the advent of colonial rule or "modern" state. While this sounds logical, reality is of course very different.

Contrary to Dillard's maxim, peoples' will can only apply within the political, not cultural boundaries that have been colonially demarcated. Weller argues that:

Self determination is not aimed to restore ethnic or tribal links among populations that were artificially divided by the colonizers. Instead, the 'people' entitled to self-determination are those who happen to live within the colonial boundaries drawn by the colonial powers. Self-determination action is taken in a way that does not fully overcome, but merely reshapes, facts on the basis of the reality of colonial administration. And it is the territorial shape of that administration that defines the self-determination entity, not the will of the people (Wellner 2005: 11).

In the history of peoples' self-determination struggles in the last 62 years after the Second World War, only Bangladesh in 1971 gained its independence from Pakistan through force of arms. The Turkish invasion of Cyprus in 1974 did not produce a state while Singapore's peaceful separation from the Federation of Malaysia in 1965 was not a result of secession but expulsion. East Timor on the other hand obtained its liberation in 1999 as a result of a de-colonization process in a UNsupervised referendum at the cost of tens of thousands of East Timorese lives lost, properties destroyed, and gross human rights violations committed by the Indonesian military.

Colonialism generates the self-determination entity and therefore defines the state that may unfold. As practiced, "peoples' will" could only apply within boundaries that have been previously defined by former colonizers. Not even different ethnic groups living in the same physical space but had been earlier ruled by different colonial masters would be entitled to form their own state, or perhaps to associate in part with 
neighboring ethnic kin states. Rather, the right to self-determination is to be employed by people who have been subjected to the same colonizer and who in turn utilizes such right as a political instrument for decolonization. The broad visions of struggle for self-governance have not been applied to multi-nation states arbitrarily created by colonizers.

The UN General Assembly Resolution 2526 (XXV) on the Declaration of Principles of International Law proclaims that the principle of equality of rights and self-determination of peoples cannot be interpreted to connote the recognition of the dismemberment and fragmentation on ethnic and religious grounds. Affirming the doctrine of territorial integrity, ethnic, religious, and sub-national cultural entities and groups can only claim territorial and political autonomy within the new state boundaries. Hence, external self-determination is an act that cannot be taken up more than once. When a colonial territory has exercised the option of independence, ethnic groups living in the new state boundaries cannot invoke the right to self-determination against the newly declared independent state. It is therefore not a continuing action against the state.

An exception to this rule, as noted by Wellner (2005: 29), would relate to a self-determination entity that does not opt to become independent but decides to associate, but not integrate, with another state. In such case, self-determination status of the entity is maintained or transformed into a situation wherein the right to self-determination can be asserted within the provisions of the state's constitution. However, there is very little practice of this kind.

Notably, in the international law literature on self-determination, two main views are pulling in opposite directions. The first tendency is the more restrictive view which limits the exercise of the right to selfdetermination within the confines of the territorial jurisdiction of existing states; the right cannot be invoked if the territorial unity of the state will be transgressed.

10 Philippine Political Science Journal 29 (52) 2008 
The second view is expansionary which acknowledges and, to varying degrees, validates recent state-busting practice in a reformulated legal approach that admits that the character and scope of the right are more unsettled than ever. This latter view takes due note of the degree to which non-sovereign territories of the Soviet Union, Yugoslavia, and Czechoslovakia were given diplomatic recognition and admitted to the UN as sovereign states.

The controversy on the principle and right to self-determination has led peoples and states to armed conflict. Struggles for autonomy and secession on the defense of peoples' national rights are politically and militarily confronted by the state, invoking its right to protect the inviolability of its territory. Peoples of the world are told they have the right to self-determination. Nevertheless, if this right is suppressed by a sovereign state, the international community supports territorial integrity until a war of independence is successful. As in the past, the entire problem is settled on the battlefield. The conflict has been the source of tremendous human suffering and destruction in Asia, Africa, and Europe.

\section{Etching self-determination in the Constitution}

As discussed earlier, the right to self-determination can be exercised in two major ways: one, through secession otherwise known as external self-determination based directly on international law and two, through constitutional means also known as internal self-determination. In the latter case, ethno-linguistic, cultural, religious or sub-national groups are said to have guaranteed political and cultural autonomy and freedom to chart their own future in accordance with the provisions of the state's constitution. Groups are thought to be permitted to establish a separate legal personality for component parts of the overall state. In fact, international law now appears to take note of constitutional selfdetermination as a possible alternative to nation-state building. As such, some countries have etched in their constitution the right to selfdetermination as a fundamental entitlement of peoples, nations, and cultural groups to build their own nation-state. Far from being exhaustive, some examples of internal self-determination are discussed. 
Article 39 (1) of the 1994 Ethiopian Constitution stipulates that certain nominated constituent entities should enjoy a right to external self-determination. It declares that "Every Nation, Nationality and People in Ethiopia has an unconditional right to self-determination, including the right to secession."10

Likewise, Article 4 (2) of the Constitution of the Principality of Liechtenstein permits each municipality to "remove itself from the statecommunity" while conditional self-determination has been awarded by the Parliament of Moldova in 1994 to the people of Gagauzia (one of the three republics - Moldova, Gagauzia, and Transnistria) the right to "external self-determination" if the status of the country would change. The Law on the Special Legal Status of Gagauzia adopted by the Parliament on 23 December 1994 declares that Gagauzia is a nationalterritorial autonomous unit that is an "integral part of the Republic" (Article 1[1]) but:

In case of a change of the status of the Republic of Moldova as an independent state, the people of Gagauzia shall have the right to external self-determination (Article 1[4]).

Many European human rights organizations recognize and promote Gagauzia as a successful model for resolving ethnic conflicts.

Although the three cases above may provide the opportunity for nations and peoples to exercise their right to self-determination sometime in the future or when conditions warrant such action, previous experience proved that the state made use of its power to frustrate peoples' attempt to secede.

A classic example of constitutional self-determination was the former Union of Socialist Soviet Republic's (USSR) constitution. Article 70 of its 1977 constitution provides that the Union, formed under the principle of socialist federation, is an integral, federal, and multinational state where nations and peoples are free to assert their right to self-

12 Philippine Political Science Journal 29 (52) 2008 
determination. While Article 72 says that "Each Union Republic shall retain the right freely to secede from the USSR," Article 73(2) assigned to the USSR jurisdiction in relation to the determination of the state boundaries of the USSR and also approval of changes in the boundaries between Union Republics.

Hence, when the Baltic states asserted their right to self-determination under Article 72 between the years 1989 and 1990, the USSR did not only use Article 73(2) but also Article 78 which provides the assignment of competence between the federation and self-determining entity to thwart peoples' attempt to gain their independence from the Union. However, the issue was resolved entirely when the USSR was dissolved in the wake of an unsuccessful coup against President Gorbachev. In this case, constitutional self-determination was not fully tested.

In like manner, the 1993 new Russian Federation's constitution reiterated the self-determination right to peoples, to wit:

We, the multi-ethnic people of the Russian Federation, united by our common destiny of our land, seeking to advance human rights and freedoms and promote civil peace and accord, preserving a historically established state unity, guided by universally recognized principles of equality and self-determination of peoples ... renewing the sovereign statehood of Russia ...

Nevertheless, Article 66.5 explicitly provides that:

The status of a member of the Russian Federation may be altered by the mutual consent of the Russian Federation and the member of the Russian Federation in accordance with a federal constitutional law.

The above constitutional provision was used when Chechnya, a full federal entity under the Russian Federation, asserted its right to selfdetermination in 1991. The Russian military labeled the Chechen freedom fighters as rebels and insurgents to justify its invasion of Chechnya and 
launched its military assault in 1994. In 1997, the Federation concluded an agreement with Chechnya which expressly recognized it as a selfdetermination entity and foresaw a resolution of the conflict in accordance with the international law. However, when the alleged Chechen terrorists attacked Moscow in December 2001, the Russian Federation unilaterally annulled that agreement and forcibly reincorporated Chechnya. The European Union (EU) supported the Federation's territorial integrity instead of the claimed rights of Chechnya to independence.

Another is the case of the former Socialist Federal Republic of Yugoslavia (SFRY). Section 1 of its 1974 constitution says:

The nations of Yugoslavia, proceeding from the right to every nation to self-determination, including the right to secession, on the basis of their will freely expressed in the common struggle of all nations and nationalities in the National Liberation War and Socialist Revolution, and in conformity with their historic aspirations, aware that further consolidation of their brotherhood and unity is in the common interest, have, together with the nationalities with which they live, united in a federal republic of free and equal nations and nationalities and founded a socialist federal community of working people-the Socialist Federal Republic of Yugoslavia...

The constitutional provision on self-determination was put to the test in 1991 when Croatia and Slovenia unilaterally declared independence from the SFRY. As in past cases, the independence movements were meted out with excessive use of military force and violence by the Belgrade government in the name of the state's right to protect its territorial boundaries and maintain territorial unity.

The USSR and SFRY experience had shown that constitutional guarantees for self-determination right are not really guarantees. The state remains an all-powerful entity which can define and re-define the

14 Philippine Political Science Journal 29 (52) 2008 
meaning and modalities of exercising the right to self-determination. However, as proven from the past, the state, in spite of the support of the international community to territorial integrity, is no match to a determined separatist movement which can instigate the dissolution of the state itself. The consequences nonetheless are unimaginably high in terms of the cost they entail on human lives, properties and infrastructures, and displacements of people.

Although the case of Canada is slightly different with reference to Quebec's (French-speaking Canadians) possible secession from the Federation, it remains consistent in terms of the role, power, and function of the state. Despite the absence of constitutional provision on selfdetermination in the Canadian constitution, its Supreme Court ruled that secession is not mandatory on the part of the state to accede even if there is "a clear majority vote in Quebec on a clear question in favor of secession...." The Court affirmed that the independence of Quebec is still subject to "good faith negotiations" between the state and the self-determining entity (Wellner 2005: 22).

Nonetheless, this was never put into practice. In the 1995 referendum, the Quebecois nationalists lost in a very close vote: $50.6 \%$ to $49.4 \%$, or only 53,498 votes out of more than 4,700,000 votes cast. Approximately $90 \%$ of Anglophones (English-speaking) and allphones (mostly immigrants and first-generations Quebecois whose native language is neither French nor English) Quebecois voted against the referendum, while almost $60 \%$ only out of $82 \%$ of Francophones (French-speaking) voted Yes to Quebec's sovereignty (NLC 2001:54).

\section{The prospect of the Moro right to self-determination}

On 11 March 2007, it was reported that a breakthrough in the long-drawn, intermittent, and unstable peace talks between the Philippine government and the MILF has been made. The government has offered Muslims in Mindanao the right to self-determination (PDI 2007: 2). However, Rudy Rodil, one of the GRP peace negotiators, clarified in the same report that although Muslim self-governance has been provided 
in all areas, this does not include "defense, foreign affairs, [and] the monetary and postal systems." While the proposal is yet to be finalized in the GRP-MILF Formal Talks, the MILF has welcomed the development. "We feel it is an advancement in the search for peace in Mindanao," says MILF Chair Murad. Silvestre Afable, then the government's chief negotiator, further noted that the "issue of territory remained unresolved," and some proposals need Congressional approval. Yet unsettled, a ray of hope has emerged. A new relationship between the state and MILF that could make continued territorial unity possible is most inspiring towards addressing the long-drawn conflict in Mindanao.

Given the general theory and common practice of self-determination in the world, it appears that the Moro struggle for external selfdetermination would be arduous at this time. The peace process currently being undertaken jointly by GRP and MILF with the participation of the OIC through Malaysia's facilitation, in spite of some violations on ceasefire agreements, gives a semblance of legitimacy on the part of the state to address the conflict within the confines of the Philippine constitution.

If there is anything that one has to learn from the experience of selfdetermination struggles of peoples in the world under the context of the international state system, it is that the right to self-determination is plainly elusive. The right to self-determination, established in the late 1950s and 1960s as a decolonization instrument, was enforceable only in relation to a small number of governments that continued to cling to colonial rule at that time. It was conceived to restore justice to nations which have been subjected to colonialism. It was never intended to destabilize existing sovereign states or states which have been freed from colonial rule. The doctrine of self-determination, more than ever, is to safeguard the territorial integrity (free from external invasion) and territorial unity (free from internal armed conflict coming from secessionist movements) of independent states.

Self-determination offers a promise of independence and liberation to peoples from a state that marginalizes and discriminates them.

16 Philippine Political Science Journal 29 (52) 2008 
Nonetheless, states know for a fact that such promise is a plain chimera. The international state system, established more than 60 years after the Second World War, has historically rendered support to states challenged by secessionist movements and groups. Moreover the state is usually given a carte blanche in dealing with groups seeking to assert their separate identity. The state system thus, gives supreme importance to "stability" rather than justice, at least as seen by groups seeking independence from a state considered as purveyor of "internal colonialism."

As discussed in the beginning of this paper, the notion of Bangsa Moro is quite new. It emerged only in 1968 in the wake of the Jabidah massacre and has yet to be crystallized. Historical facts attest that the shifting of Muslim identities from the time the Republic gained its independence from the Americans until late 1960s indicates the hollowness of Moro consciousness and concept of a Bangsa Moro.

It took Misuari's MNLF, in the course of its anti-Muslim elite and anti-dictatorial struggle against Marcos, to remind his Muslim brethrens that they have to re-claim their homeland and redeem the Moro nationstate from the Philippine state. In a nationalist project such as the MNLF's separatist movement, the attempt to wrest control of a proclaimed national territory from the illegitimate seizure of another state regarded as alien, is the overarching feature. The MILF is not an exemption. All MNLF and MILF informants in the study traced the historical roots of the Moro identity and Bangsa Moro centuries before the advent of colonialism. From their perspective, the Moro nation-state has already existed that never succumbed to colonial rule but illegitimately annexed by the current Philippine republic. Mastura's undated manuscript, "Mindanao Conflict: Political and Territorial Framework", is a good attempt to abstract the historical roots of Moro nation-state building within the framework of international law.

Understandably, the Bangsa Moro requires a history, an imagined national past that is essential in the quest and process of nation-building. A nation is "an imagined political community - (one) imagined as both 
inherently limited and sovereign" where people "not so much to kill, as willingly to die for such limited imaginings" (Anderson 1983: 15, 16). For Anderson, the imagined community of the nation is a mass fiction. It is not clear, however, who, if anyone, imagines a particular community and if there is any difference in the resulting fictional community, depends on who imagines it and how one does so. Invariably, the history of the Muslims during the Spanish era, as narrated by some nationalist movements, culling uncritically from accounts of historians, to a certain extent requires a more scholarly and independent analysis, an important concern which this paper cannot deal with at the moment.

Nevertheless, what is important for them is that stories should be generally believed or that there should be substantial convergence in the versions of a story that are to be believed. Stories are not only needed at the time during which a national identity is being created, it is also required for one to understand what it means to be a Bangsamoro (referring to the Moro people) and one has to accept a version or some versions of the common story to grasp the significance of one's identity.

In other words, historical accuracy is not vital in constituting a nation since the story is told for the purpose of self-definition. And Bangsa Moro's self-definition bears on the goals that its members will try to pursue in the future. Leaders of separatist movements have to defy the modern state in which they are found, challenge their authority, and confront their armed forces. They present themselves as rulers as well as rebels in order to supplant the jurisdiction of the alienized state with their own localized version. History making or myth making is in part and parcel an idea in the whole process of nation-creation.

If the MILF (which now leads the struggle for Muslim selfdetermination) has to pursue its bid for Muslim independence, it needs to prove that its case is a decolonization issue aside from fully satisfying the stringent criteria of statehood (territory, population, effective government) as required by the international community. However, it appears that the question of decolonization would be a tenuous issue in

18 Philippine Political Science Journal 29 (52) 2008 
as much as the Moroland - Mindanao, Sulu archipelago, and Palawan - has been part of the Philippine nation-state when the former American colonizers granted the Philippines its independence in 1946. Likewise, the principle of equality of rights and self-determination of peoples refrains a state from any partial or total disruption of one's territorial integrity (UNGA Res. 2526 [XXV]).

Experience has demonstrated that the state system is inclined to defend and safeguard the sovereign state's territory. The probability of endorsing the right to the state to its territorial unity over the MILF's case of self-determination is therefore highly to be bestowed by the international community.

An alternative to external self-determination is to seek substantial and meaningful political and cultural autonomy within the Philippine political system not necessarily within the current presidential unitary system as defined in the constitution. Conferring a semi-sovereign status resembling a federal structure of governance to Muslim areas of Mindanao would be an option that the state can work on to further the nation-state building not only of the Philippines but also of the Muslims. A "unified approach" (Kingsbury 1992: 481-513) in bringing together various ethnic, religious, and national groups into the Philippine nationstate in general and Mindanao in particular can be a promising politicoadministrative instrument in dealing with the complexity of living in a physical environment where people of differing ethnicities, religious beliefs, and cultures thrive and prosper, and conflicts are resolved and justice claimed in a non-violent means.

In other words, internal self-determination would be a better, less violent, and workable choice that the MILF can take. Nevertheless, pursuing internal self-determination in the long term necessitates the state to comprehend fully the root causes of Moros' self-determination struggle. Unless the rationale behind secessionism is appreciated and resolved to its conclusion through sustained, comprehensive, coherent, and appropriate national policies coupled with effective and methodical policy implementation, secessionism would continue to inspire the Moros in search for valuable political power and social justice. 


\section{Conclusion}

The internationally-recognized right to self-determination is an offer to peoples and nations to become independent from the state. However, the international state system assures that this offer is less than useful to those who need it. States are guaranteed of their right to preserve the integrity of their territory. The state system has been rigged to ensure that central governments will prevail in self-determination conflicts. This has been the reality over 60 years after the establishment of the postWorld War II international system.

The offer of the Philippine government of the right to selfdetermination to the MILF is a clear case that the proposal does not go beyond the impairment of the state's territory. Experiences from the world indicate that states thwart the right to self-determination by offering wideranging self-government and power-sharing or even provide a possibility of separation, often after a prolonged interim period. Some Muslim scholars subscribed to the latter (Lingga 2007). In the Philippines where peace agreements are seldom respected and had been subject to the changing power configuration of the state, concurring to a long-term debate on issues of self-determination prior to an agreed referendum is tantamount to a delayed if a denial of an opportune and steadfast resolution of conflict.

The paper concludes that the right to self-determination cannot be simply invoked by those who consider themselves as a "separate" people from the rest of the population inhabiting the current state. Although a guaranteed right provided by the international community to indigenous peoples, minorities, and nations, states are not in any way obligated and compelled to assure such right is executed in accordance with the "spirit and letter" of self-determination covenants. Drawing from the experience and trends in self-determination, the Moros' effort to secede from the Philippine state is bound to face stiff resistance not only from the Republic but also from other states confronted with similar problems relative to secessionism. The paper further contends that the threat of national disintegration will continue until an appropriate institutional

20 Philippine Political Science Journal 29 (52) 2008 
framework for political governance which can accommodate Mindanao's social and ethnic diversity is ensconced.

The paper suggests that it has to train its attention on a more feasible alternative - assert their right to self-determination internally rather than externally. While there is no assurance that meaningful Bangsamoro selfgovernance would transpire under a unitary presidential system, new forms of co-governance may be tested to build the Philippine nationstate.

\section{Notes}

1 The term Moro was the name used by the Spaniards to refer to Muslim inhabitants in the Philippines alluding to the Muslim Moorish occupation of the Iberian Peninsula (Spain and Portugal) and the northern coast of the African continent in 711 A.D. In 16 th century, the Spaniards encountered the ferocious resistance of Muslims inhabiting the Southern Sultanates of the country in their attempt to colonize the archipelago. This reminded them of their ancient enemy, the Moors, thus called the Philippine Muslims Moros (Phelan 1959: 4-8; Corpuz 1989: 46).

2 It was accounted that the creation of MIM was Datu Udtog Matalam's personal response to traditional filthy electoral system in Cotabato that had been disadvantageous to his political ambitions rather than a reaction to the Jabidah massacre and an intention to carve a separate state from the Philippines (McKenna 1998: 144-149).

${ }^{3}$ The word Moro was later dropped from BMLO as it remains unacceptable to many of the Muslims. BMLO adopted Bangsa Muslimin Islamic Liberation Organization (BMILO) as its new name in 1984 (Jubair 1999: 152).

${ }^{4}$ The term bangsa or bansa is a Malay word that usually refers to nations, castes, descent groups or lines, races or estates. Informants of this study prefer to use it as one word, Bangsamoro. For the purpose of this paper, Bangsa Moro shall be used to mean the "Moro Nation" as imagined by Filipino Muslims and Bangsamoro to refer to the "people" inhabiting the Philippines.

${ }^{5}$ The Organization of Islamic Conference (OIC), founded in 1971, comprises 54 countries (including the non-state, Palestine). One of its major activities is to settle conflicts by peaceful means, mainly through mediation, negotiation, and arbitration. The OIC had been instrumental in forging the 1976 and 1996 GRP-MNLF Tripoli Agreement and Final Peace Agreement respectively.

${ }^{6}$ MILF was a breakaway group from MNLF headed by Salamat Hashim, a Maguindanaoan. It started as a reformist group in 1977, then known as New MNLF, that advocated for autonomy rather than independence to enable it to negotiate with the then Marcos 
government and woo the support of the OIC when Misuari became intransigent that threatened the collapse of the 1976 Tripoli Agreement signed between the MNLF and GRP. Unsuccessful in his attempts, Hashim renamed his organization in 1984 as the Moro Islamic Liberation Front and made Islam as its official ideology.

7 "The Moro Struggle for Self-Determination and the Moro Islamic Liberation Front." Available from: http://www.db.idpproject.org/Sites/IdpProjectDb/idpSurvey.nsf/ AllDocWeb/4F62C40ACE5A0370C12568F70058401C/\$file/MILF_selfdetermination.PDF. (Accessed on 02 February 2007).

8 "Murad extends greetings of peace and solidarity to Muslim believers", 10 November 2003 News. Available from: <http://www.luwaran.com/> (Accessed on 29 March 2003).

9 This doctrine is, however, displaced in certain circumstances, in cases of territorial change that are anticipated in historical arrangements such as the hand-over of Hong Kong (see Marc Weller, "Self-determination trap," Ethnopolitics 4: 1, 3-28 March 2005, p. 7).

${ }^{10}$ Article 39 (5) defines "nation, nationality and people" as follows:

A 'Nation, Nationality or People' for the purpose of this Constitution, is a group of people who have or share a large measure of a common culture or similar customs, mutual intelligibility of language, belief in a common or related identities, a common psychological make-up, and who inhabit an identifiable, predominantly contiguous territory.

\section{References}

\section{Books, Journal Articles, and Conference/Briefing Papers}

Anderson, Benedict. 1983. Imagined Communities: Reflections on the Origin and Spread of Nationalism, rev. ed. 1991. Verso: London, New York.

Buendia, Rizal G. 2005. "The State-Moro Armed Conflict in the Philippines: Unresolved National Question or Question of Governance." Asian Journal of Political Science 13: 1, June.

Corpuz, Onofre D. 1989. The Roots of the Filipino Nation, Vols. 1 and 2. Quezon City: AKLAHI Foundation, Inc.

Gowing, Peter. 1979. Muslim Filipinos: Heritage and Horizon. Quezon City: New Day Publishers.

Jubair, Salah. 1999. Bangsamoro: A Nation Under Endless Tyranny. Lahore: Islamic Research Academy.

Kingsbury, Benedict. 1992. "Claims by Non-State Groups in International Law." Cornell International Law Journal 3: 25.

22 Philippine Political Science Journal 29 (52) 2008 
Lingga, Abhoud Syed M. 2002. "Referendum: A Political Option for Mindanao." Paper presented at the Mindanao Tripeoples Caucus, Royal Hotel Mandaya, Davao City. September 10-12.

2007. "Bangsamoro Self-Determination." Paper read at the International Roundtable Conference on Right to Self-Determination of Peoples, 16-18 July, Makati City, Philippines.

Mastura, Michael. (undated). "Mindanao Conflict: Political and Territorial Framework" (manuscript).

McKenna, Thomas. 1998. Muslim Rulers and Rebels: Everyday Politics and Armed Separatism in the Southern Philippines. Los Angeles, California: University of California Press, Berkeley.

National Library of Canada (NLC). 2001. Instruments of direct democracy in Canada and Québec, 3rd edition.

Phelan, John Leddy. 1959. The Hispanization of the Philippines. Wisconsin: University of Wisconsin Press.

Tan, Samuel. 1993. Internationalization of the Bangsamoro Struggle. Quezon City: The Center for Integrative and Development Studies, University of the Philippines.

Weller, Marc. 2005. "Self-determination trap." Ethnopolitics 4:1, 3-28 March.

Williams, C.H. 1988. "Minority Nationalist Historiography." In R.J. Johnston, D.B. Knight \& E. Kofman (eds.), Nationalism, Self Determination and Political Geography. New York: Croom Helm.

\section{Official Documents}

The Constitution of the Republic of the Philippines, 1987, 1973, and 1935.

The United Nations (UN), General Assembly Resolution 1514 (XV), Declaration on the Granting of Independence to Colonial Countries and Peoples, New York: 14 December 1960.

Universal Declaration of Human Rights, United Nations, Geneva 1978.

The United Nations, General Assembly Resolution 2625 (XXV), Declaration of Principles Concerning Friendly Relations Among States, New York: 24 October 1970.

International Covenant on Civil and Political Rights, Third periodic reports of States parties due in 1991, Addendum, Report Submitted by Sri Lanka, 18 July 1994, CCPR/ C/70/Add.6, 27 September 1994.

UN General Assembly 2526 (XXV) on the Declaration of Principles of International Law. 
International Court of Justice Reports (New York: I.C.J. Report, 1975).

1974 Socialist Federal Republic of Yugoslavia (SFRY) Constitution.

1977 USSR Constitution.

1993 Russian Federation Constitution.

Constitution of the Principality of Liechtenstein.

The Law on the Special Legal Status of Gagauzia 23 December 1994.

1994 Ethiopian Constitution.

\section{Newspapers/Magazines/Newswires}

Dansalan Quarterly "Manifesto of the Muslims of the Philippines Supporting the Call for National Reconciliation and Unity," 7 October 1983.

Philippine Daily "Gov't offers Moros right to self-determination." 11 March 2007.

Philippine Star A.B. Corvera, "Nur Misuari: Has the 'good warrior's' long struggle come to a disgraceful end?" 16 January 2002, in http://www.philstar.com/philstar/ misua.htm (accessed on 12 October 2003).

24 Philippine Political Science Journal 29 (52) 2008 